\title{
Keanekaragaman Jenis Satwa Burung di Areal Mangrove Desa Passo Kecamatan Teluk Ambon Baguala Kota Ambon
}

\author{
(Diversity of Bird Species in the Mangrove Area of Passo Village, Teluk Ambon Baguala \\ District, Ambon City)
}

\author{
Maya. M. S. Puttileihalat ${ }^{1}$, A. Tuhumury ${ }^{1} \&$ J.Ch. Hitipeuw ${ }^{1}$ \\ 1 Jurusan Kehutanan, Fakultas Pertanian, Universitas Pattimura, Ambon 97233 \\ Email : maya.puttileihalat@faperta.unpatti.ac.id
}

\begin{abstract}
Mangrove forests have many functions, one of which is a habitat for various water birds and birds. Birds make mangroves a habitat to find food, breed, or just rest. Birds that can be found in mangrove forests can be birds that live and nest in mangrove forests and birds that come from other habitats that only occasionally visit mangroves to find food or rest. The research method used is the Point Count method, where the observation technique is carried out at a point, and the observations are carried out over a certain period. The number of bird species recorded in the mangrove area of Passo Village was 11 species from 9 genera, seven families, and seven orders. The average number of individuals recorded during the research activity was 197 individuals. $72.73 \%$ of the composition of bird species in the mangrove area of Passo Village are waterbird species, including four orders from a total of 7 charges, and four families from a total of 7 families, and six genera from a total of 9 genera; while the other $27.27 \%$ are terrestrial bird species.
\end{abstract}

KEYWORD: Diversity of species, birds, mangroves,

\section{INTISARI}

Hutan mangrove memiliki banyak fungsi, salah satunya yaitu sebagai habitat bagi berbagai jenis burung air serta beberapa jenis burung. Burung menjadikan mangrove sebagai habitat untuk mencari makan, berkembangbiak atau sekedar istirahat. Burung-burung yang dapat dijumpai di hutan mangrove dapat berupa burung yang tinggal dan bersarang di hutan mangrove serta burung yang berasal dari habitat lain yang hanya sekali-sekali mengunjungi mangrove untuk mencari makan ataupun beristirahat. Metode penelitian yang digunakan adalah metode Point Count, dimana teknik pengamatan dilakukan pada suatu titik dan pengamatan dilaksanakan selama periode waktu tertentu. Jumlah jenis satwa burung yang tercatat di areal mangrove Desa Passo sebanyak 11 jenis dari 9 genus, 7 famili, dan 7 ordo. Rerata jumlah individu yang tercatat selama kegiatan penelitian adalah sebanyak 197 ekor. 72,73 \% komposisi jenis burung di areal mangrove Desa Passo merupakan jenis-jenis burung air, meliputi 4 ordo dari total 7 ordo, dan 4 famili dari total 7 famili, serta 6 genus dari total 9 genus; sedangkan 27,27 \% lainnya merupakan jenis-jenis burung terestrial.

KATA KUNCI : Keanekaragaman jenis, burung, mangrove.. 
Keanekaragaman jenis satwa burung di areal mangrove Desa Passo Kecamatan Teluk Ambon Baguala (Maya. M. S. Puttileihalat, A. Tuhumury, J.Ch. Hitipeuw)

\section{PENDAHULUAN}

Hutan mangrove merupakan hutan yang tumbuh pada tanah lumpur aluvial di daerah pantai berlumpur dan di sekitar muara sungai yang dipengaruhi pasang surut air laut. Vegetasi hutan mangrove didominasi oleh jenis-jenis pohon dari marga Avicennia, Sonneratia, Rhizophora, Bruguiera, Ceriops, Lumnitzera, Excoecaria, Xylocarpus, Aegiceras, Scyphyphora, dan Nypa. Hutan mangrove dicirikan oleh struktur tajuk vegetasi pohon yang seragam dan sederhana. Hutan mangrove memiliki banyak fungsi, salah satunya yaitu sebagai habitat bagi berbagai jenis burung air serta beberapa jenis burung daratan (Alikodra et al. 1989; Mustari 1992; Kusmana et al. 2003,). Burung menjadikan mangrove sebagai habitat untuk mencari makan, berkembangbiak atau sekedar istirahat. Burung-burung yang dapat dijumpai di hutan mangrove dapat berupa burung yang tinggal dan bersarang di hutan mangrove serta burung yang berasal dari habitat lain yang hanya sekali-sekali mengunjungi mangrove untuk mencari makan ataupun beristirahat.

Burung merupakan satwa yang mempunyai peranan penting sebagai indikator keanekaragaman hayati sekaligus indikator terhadap perubahan kualitas suatu lingkungan hidup dari aspek ekologis. Status populasi dari suatu jenis burung dapat dijadikan sebagai petunjuk tentang jenis dan skala dampak terhadap lingkungan hidup dan ekosistem akibat aktivitas eksploitatif dan desktruktif oleh manusia (Irby J. Lovette, \& John W. Fitzpatrick, 2016). Relung ekologi komunitas burung yang cenderung dekat atau berada pada bagian atas tingkat trofik rantai makanan membuat beberapa jenis burung sangat peka terhadap perubahan pada tingkat trofik yang lebih rendah (Koskimies, 1989; Gregory et al., 2005 dalam Fraixedas et al., 2020).

Keberadaan burung-burung di suatu tempat sangat dipengaruhi oleh berbagai faktor yang sangat kompleks, diantaranya adalah faktor abiotik berupa iklim (curah hujan dan temperatur), serta faktor biotik berupa ketersediaan sumber makanan, kehadiran spesies-spesies kompetitor, dan kehadiran predator (Walter, 2016). Beberapa spesies burung memiliki toleransi yang cukup luas terhadap berbagai faktor biotik dan abiotik, dan sebaliknya spesies-spesies yang lain memiliki toleransi yang sempit yang berpengaruh terhadap distribusi dan kelimpahan spesies-spesies burung pada suatu habitat.

Kerusakan dan hilangnya habitat merupakan salah satu ancaman serius terhadap keanekaragaman jenis burung di suatu tempat. Irwan (1992), menyatakan bahwa keanekaragaman akan cenderung lebih rendah dalam ekosistem-ekosistem yang secara fisik tidak terkendali oleh faktor biologi. Habitat dapat mencakup berbagai tipe ekosistem, mulai dari ekosistem alami sampai ekosistem buatan. Habitat merupakan bagian penting bagi distribusi dan jumlah burung dalam suatu kawasan. Bagi kawasan yang tidak dilindungi, habitat tentu akan mengalami perubahan penggunaan lahan.

Salah satu hutan mangrove di kota Ambon adalah mangrove di desa Passo Kecamatan Teluk Ambon Baguala. Mangrove pada lokasi ini merupakan mangrove yang termasuk dalam kawasan Lindung dengan jenis-jenis mangrove yang mendominasi adalah mangrove dengan jenis soneratia alba 
dan rhizopora sp. Berdasarkkan uraian diatas, penelitian ini bertujuan untuk menganalisis keanekaragaman jenis satwa burung di areal mangrove desa Passo Kecamatan Teluk Ambon Baguala, Kota Ambon.

\section{METODE PENELITIAN}

\section{Lokasi dan Waktu Penelitian}

Penelitian ini dilaksanakan di Areal Mangrove Desa Passo Kecamatan Teluk Ambon Baguala, Kota Ambon dari tanggal 18 s/d 29 November 2019. Peta lokasi penelitian disajikan pada Gambar 1.

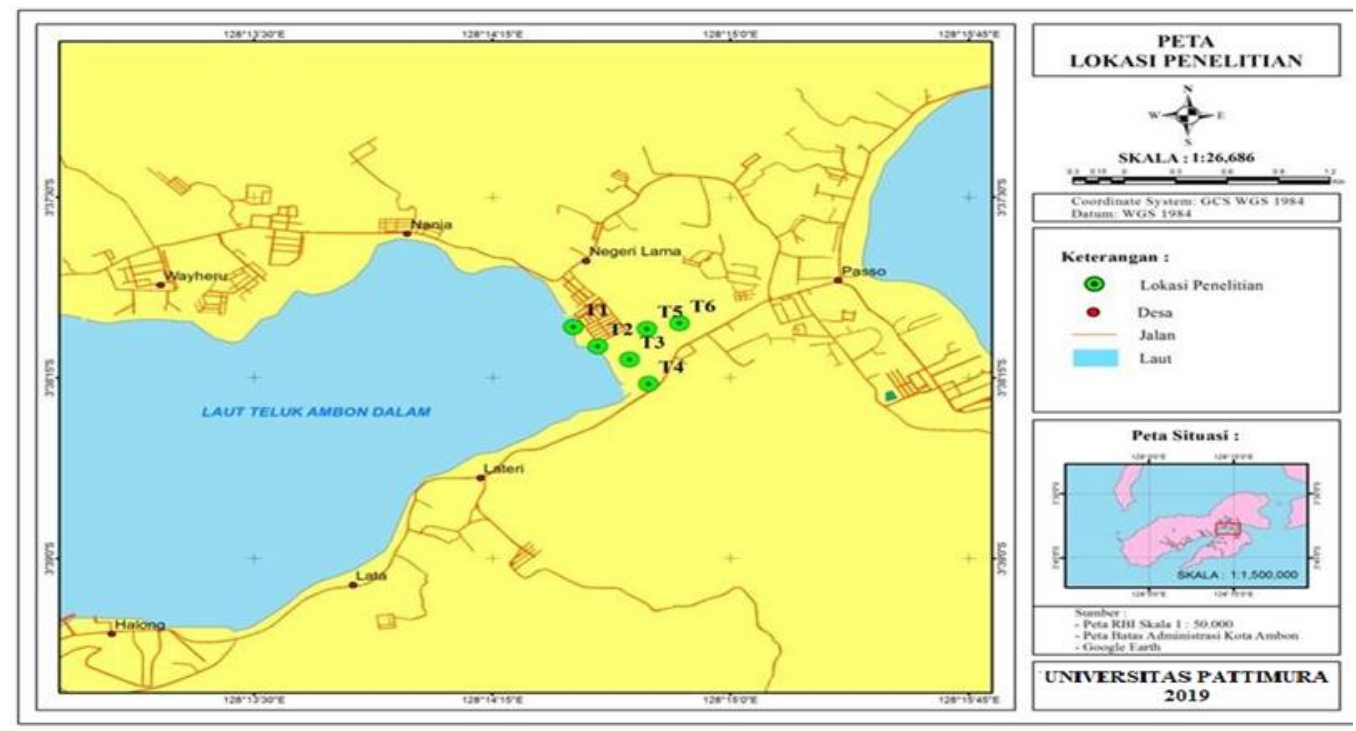

Gambar 1. Peta Lokasi Penelitian

\section{Alat dan Bahan Penelitian}

Alat yang digunakan dalam kegiatan penelitian ini meliputi, Binokuler untuk membantu melakukan pengamatan burung pada jarak jauh, Buku Panduan Lapangan Burung-Burung di Kawasan Wallacea digunakan untuk mengidentifikasi jenis burung yang teramati, Tally sheet digunakan untuk mencatat parameter-parameter yang diamati, Kamera untuk dokumentasi kegiatan penelitian, GPS untuk penentuan koordinat titik-titik point count, Stopwatch untuk perhitungan waktu pengamatan pada tiap titik-titik pengamatan, dan Alat tulis menulis. Bahan dari penelitian ini adalah populasi satwa burung yang berada di areal mangrove Desa Passo Kecamatan Teluk Ambon Baguala, Kota Ambon.

\section{Desain dan Prosedur Penelitian}

Berdasarkan tujuan penelitian, maka desain penelitian yang digunakan adalah desain penelitian deskriptif, dimana karakteristik utama dari penelitian ini adalah peneliti hanya dapat melaporkan apa yang terjadi pada variabel, dan tidak dapat mengontrol variabel penelitian. Sedangkan bila dilihat jenis data yang digunakan, maka penelitian ini termasuk dalam penelitian kuantitatif, dimana kegiatan penelitian didasarkan pada pengukuran secara kuantitatif pada berbagai variabel penelitian. 
Keanekaragaman jenis satwa burung di areal mangrove Desa Passo Kecamatan Teluk Ambon Baguala (Maya. M. S. Puttileihalat, A. Tuhumury, J.Ch. Hitipeuw)

Metode penelitian yang digunakan adalah metode Point Count, dimana teknik pengamatan dilakukan pada suatu titik dan pengamatan dilaksanakan selama periode waktu tertentu. Buckland $e t$ al (2001), menyatakan bahwa titik-titik pengamatan pada dasarnya dapat diletakan secara acak di dalam areal survei, atau dapat juga diletakan pada suatu garis lurus dengan interval tertentu. Dalam penelitian ini titik-titik Point Count diletakkan secara acak pada lokasi penelitian di areal mangrove desa passo. Dengan demikian akan dibuat 6 titik point count untuk pengamatan burung, dengan jarak antara titik $\pm 200 \mathrm{~m}$ dan pengambilan data pada setiap titik Point Count dilakukan selama \pm 20 menit.

Menurut Buckland et al (2001), Metode Point Count harus memenuhi asumsi-asumsi sebagai berikut :

a. Satwa yang berada pada jangkauan titik pengamatan harus selalu terdeteksi.

b. Satwa yang terdeteksi dicatat berdasarkan posisi awalnya, yaitu sebelum satwa tersebut bergerak sebagai respon dari kehadiran pengamat.

c. Jarak diukur secara tepat.

\section{Variabel Penelitian dan Analisis Data}

Variabel yang digunakan dalam kegiatan penelitian ini adalah variabel keanekaragaman jenis burung. Keanekaragaman jenis disebut juga dengan heterogenitas jenis merupakan ciri unik untuk menggambarkan struktur komunitas. Suatu komunitas dikatakan mempunyai nilai keanekaragaman jenis tinggi apabila memiliki kelimpahan masing-masing jenis yang merata.

Keanekaragaman jenis burung diukur dengan cara mencatat jumlah individu suatu jenis burung, dan jumlah total individu seluruh jenis burung di lokasi penelitian. Variabel keanekaragaman jenis dihitung menggunakan persamaan Indeks Keanekaragaman Jenis ShannonWiener :

$$
H^{\prime}=-\sum_{i=1}^{s} p i \ln p i \quad p i=\frac{n i}{N}
$$

Dimana : $\quad \mathrm{n}_{\mathrm{i}}=$ Jumlah individu suatu jenis

$\mathrm{N}=$ Jumlah individu seluruh jenis

$\mathrm{H}^{\prime}=$ Indeks Keanekaragaman Shannon-Wiener

Jenis burung yang dominan ditentukan dengan menggunakan indeks dominasi menurut Helvoort (1981) :

$$
D_{i}=\frac{n i}{N} \times 100 \%
$$

Kriteria : $\quad \begin{array}{ll}\mathrm{D}_{\mathrm{i}} & =0-2 \%(\text { jenis tidak dominan) } \\ & \mathrm{D}_{\mathrm{i}}=2-5 \%(\text { jenis subdominan) } \\ & \mathrm{D}_{\mathrm{i}}=>5 \%(\text { jenis dominan) }\end{array}$ 


\section{HASIL DAN PEMBAHASAN}

\section{Keanekaragaman Jenis}

Hasil penelitian menunjukkan jumlah jenis satwa burung yang tercatat di areal mangrove Desa Passo sebanyak 11 jenis dari 9 genus, 7 famili, dan 7 ordo. Rerata jumlah individu yang tercatat selama kegiatan penelitian adalah sebanyak 197 ekor.

Tabel 1. Komposisi Jenis Burung di Areal Mangrove Desa Passo

\begin{tabular}{|c|c|c|c|c|c|c|}
\hline No & Ordo & No & Famili & No & Jenis Burung & Nama Ilmiah \\
\hline \multirow[t]{2}{*}{1.} & Coraciiformes & 1. & Alcedinidae & 1. & Cekakak Sungai & Todirhampus chloris \\
\hline & Charadriiformes & 1. & Sternidae & 1. & Dara Laut Batu & Onychoprion anaethetus \\
\hline \multirow[t]{3}{*}{2.} & & 2. & Scolopacidae & 1. & Gajahan Besar & Numenius arquata \\
\hline & & & & 2. & Gajahan Kecil & Numenius minutus Gould \\
\hline & & & & 3. & Trinil Pantai & Actitis hypoleucos \\
\hline 3. & Passeriformes & 1. & Nectariniidae & 1. & Burung Madu Sriganti & Nectarinia jugularis \\
\hline \multirow[t]{2}{*}{4.} & Pelecaniformes & 1. & Ardeidae & 1. & Kokokan Laut & Butorides striatus \\
\hline & Ciconiformes & & Ardeidae & 1. & Kuntul Karang & Egretta sacra \\
\hline 5. & & 1. & & 2. & Kuntul Kecil & Egretta garzetta \\
\hline 6. & Suliformes & 1. & Phalacrocoracidae & 1. & Pecuk Padi Belang & Microcarbo melanoleucos \\
\hline 7. & Apodiformes & 1. & Apodidae & 1. & Walet Sapi & Collocalia esculenta \\
\hline
\end{tabular}

Jenis-jenis burung yang ditemukan di lokasi penelitian merupakan perpaduan antara jenisjenis burung air dan burung-burung terestrial. Hal ini disebabkan karena ekosistem areal mangrove di desa Passo merupakan ekosistem ekoton atau peralihan antara ekosistem darat dengan ekosistem laut, karena keunikan inilah areal mangrove di Desa Passo dapat menampung keanekaragaman jenis burung, baik itu burung air (jenis burung yang menghabiskan sebagian besar aktivitas hidupnya pada unit-unit lahan basah) maupun burung terestrial.

Tabel 2. Komposisi Jenis Burung di Areal Mangrove Desa Passo

\begin{tabular}{|c|c|c|c|c|c|c|}
\hline No & Jenis & Nama Ilmiah & Famili & Ordo & Ket & Status Konservasi \\
\hline 1. & Cekakak Sungai & Todirhampus chloris & Alcedinidae & Coraciiformes & BT & Tidak dilindungi \\
\hline 2. & Dara Laut Batu & Onychoprion anaethetus & Sternidae & Charadriiformes & BA & P.106/MENLHK/SETJEN/KUM.1/12/2018 \\
\hline 3. & Gajahan Besar & Numenius arquata & Scolopacidae & Charadriiformes & BA & Tidak dilindungi \\
\hline 4. & Gajahan Kecil & Numenius minutus Gould & Scolopacidae & Charadriiformes & BA & P.106/MENLHK/SETJEN/KUM.1/12/2018 \\
\hline 5. & $\begin{array}{l}\text { Burung Madu } \\
\text { Sriganti }\end{array}$ & Nectarinia jugularis & Nectariniidae & Passeriformes & BT & Tidak dilindungi \\
\hline 6. & Kokokan Laut & Butorides striatus & Ardeidae & Pelecaniformes & BA & Tidak dilindungi \\
\hline 7. & Kuntul Karang & Egretta sacra & Ardeidae & Ciconiformes & $\mathrm{BA}$ & Tidak dilindungi \\
\hline 8. & Kuntul Kecil & Egretta garzetta & Ardeidae & Ciconiformes & $\mathrm{BA}$ & Tidak dilindungi \\
\hline 9. & Pecuk Padi Belang & Microcarbo melanoleucos & Phalacrocoracidae & Suliformes & $\mathrm{BA}$ & Tidak dilindungi \\
\hline 10. & Trinil Pantai & Actitis hypoleucos & Scolopacidae & Charadriiformes & BA & Tidak dilindungi \\
\hline 11. & Walet Sapi & Collocalia esculenta & Apodidae & Apodiformes & BT & Tidak dilindungi \\
\hline
\end{tabular}

Sumber : Data Primer, 2019. BT (Burung Terestrial); BA (Burung Air) 
Keanekaragaman jenis satwa burung di areal mangrove Desa Passo Kecamatan Teluk Ambon Baguala (Maya. M. S. Puttileihalat, A. Tuhumury, J.Ch. Hitipeuw)

Dari Tabel 2 diatas dapat dijelaskan bahwa 72,73 \% komposisi jenis komunitas burung di areal mangrove Desa Passo merupakan jenis-jenis burung air, meliputi 4 ordo dari total 7 ordo, dan 4 famili dari total 7 famili, serta 6 genus dari total 9 genus; sedangkan 27,27 \% lainnya merupakan jenisjenis burung terestrial. Hal ini dapat disebabkan karena ekosistem areal mangrove di Desa Passo mampu menyediakan sumber pakan penting bagi burung-burung air berupa gastropoda, krustacea, yang hanya dapat ditemukan di daerah pasang-surut air laut pada areal mangrove desa Passo.

Rerata jumlah individu yang tercatat, walet sapi (Collocalia esculenta) merupakan jenis dengan rerata jumlah individu tertinggi (>10\%), yakni 25,11 \%; diikuti oleh trinil pantai (Actitis hypoleucos) 15,89 \%; gajahan kecil 12,68 \%; dan burung madu sriganti (Nectarinia jugularis) 10,99 \%. Sedangkan jenis-jenis yang lainnya memiliki nilai rerata jumlah individu yang kurang dari $10 \%$. Uraian di atas juga merupakan gambaran terhadap tingkat dominasi suatu jenis dalam komunitas burung di areal mangrove Desa Passo. Jenis-jenis burung yang tergolong dalam kategori dominan dalam komunitas burung di areal mangrove Desa Passo terdiri dari 8 jenis, meliputi : walet sapi $(25,11 \%)$, trinil pantai $(15,89 \%)$, gajahan kecil (12,68 \%), burung madu sriganti (10,99\%), cekakak sungai $(9,64 \%)$, pecuk padi belang (6,42\%), kuntul kecil (6,09\%), dan kuntul karang (5,07 \%). Jenis-jenis burung yang masuk dalam kategori subdominan terdiri dari 2 jenis burung, yaitu : kokokan laut (4,40\%), dan gajahan besar (2,37 \%); dan jenis burung yang tergolong kategori tidak dominan hanya 1 jenis, yakni dara laut batu $(1,35 \%)$.

Jika dilihat pada masing-masing titik pengamatan, maka jumlah jenis dan rerata jumlah individu burung yang tercatat dapat diuraikan sebagai berikut : stasiun/titik hitung 1 dengan 5 jenis dan rerata jumlah individu sebanyak sebanyak 44 ekor, stasiun/titik hitung 2 dengan 6 jenis dan rerata jumlah individu sebanyak sebanyak 44 ekor, stasiun/titik hitung 3 dengan 5 jenis dan rerata jumlah individu sebanyak sebanyak 44 ekor, stasiun/titik hitung 4 dengan 4 jenis dan rerata jumlah individu sebanyak 33 ekor, stasiun/titik hitung 5 dengan 3 jenis dan rerata jumlah individu sebanyak sebanyak 52 ekor, dan stasiun/titik hitung 6 dengan 3 jenis dan rerata jumlah individu sebanyak 53 ekor.

Berdasarkan hasil analisis Shannon-Wienner, dapat dijelaskan bahwa keanekaragaman jenis komunitas burung di areal mangrove Desa Passo tergolong sedang, ini ditunjukkan dengan nilai indeks keanekaragaman sebesar 2,15 $\left(1<\mathrm{H}^{\prime}<3\right)$. Hal ini menggambarkan kemampuan komunitas burung pada areal mangrove Desa Passo dalam merespon gangguan tergolong sedang. Dengan demikian terdapat kecenderungan terhadap penurunan nilai keanekaragaman jenis bila terjadi gangguan terhadap lingkungan atau habitat di areal mangrove Desa Passo yang dapat berpengaruh terhadap kestabilan dan kemantapan struktur komunitas burung. 
Tabel 3. Komposisi Jenis Burung berdasarkan Tingkat Dominasi Jenis

\begin{tabular}{|c|c|c|c|}
\hline No & Kategori Dominasi & No. & Jenis \\
\hline \multirow[t]{8}{*}{1.} & Dominan & 1. & Walet Sapi (Collocalia esculenta) \\
\hline & & 2. & Trinil Pantai (Actitis hypoleucos) \\
\hline & & 3. & Gajahan Kecil (Numenius minutus Gould) \\
\hline & & 4. & Burung Madu Sriganti (Nectarinia jugularis) \\
\hline & & 5. & Cekakak Sungai (Todirhampus chloris) \\
\hline & & 6. & Pecuk Padi Belang (Microcarbo melanoleucos) \\
\hline & & 7. & Kuntul Kecil (Egretta garzetta) \\
\hline & & 8. & Kuntul Karang (Egretta sacra) \\
\hline \multirow[t]{2}{*}{2.} & Sub dominan & 1. & Kokokan Laut (Butorides striatus) \\
\hline & & 2. & Gajahan Besar (Numenius arquata) \\
\hline 3. & Tidak dominan & 1. & Dara Laut Batu (Onychoprion anaethetus) \\
\hline
\end{tabular}

Sumber : Data Primer 2019

Terdapat beberapa faktor yang mempengaruhi keanekaragaman jenis burung dalam suatu kawasan, antara lain : (1). Variasi habitat; hasil pengamatan di lapangan menunjukkan bahwa variasi habitat tergolong rendah, hal ini terlihat dari enam stasiun/titik hitung yang telah dibuat, lima stasiun/titik hitung diantara terdiri dari tipe vegetasi Rhizophora dan Soneratia, dan hanya satu stasiun/titik hitung yang terdiri dari vegetasi nipa. (2). Struktur vertikal tegakan; struktur vertikal tegakan pada areal mangrove Desa Passo umumnya hanya terdiri dari dua strata, yakni strata C dan strata D. (3). Kerusakan habitat/lingkungan, dapat berupa berkurangnya luasan areal mangrove akibat pembukaan areal di sekitar mangrove. luas hutan mangrove di Kecamatan Teluk Ambon Baguala mengalami perubahan, yaitu pada tahun 2005 memiliki luas 41.955 ha, sedangkan pada tahun 2009 menjadi 37.651 ha dengan perubahan luas sebesar 4.304 ha atau 10,25\% dan tahun 2014 luas hutan mangrove tersebut menjadi 31.379 ha dengan luas perubahan sebesar 6.272 ha atau 16,65\% (Saptono, Chatarina, \& Sigit, 2016).

Nilai indeks keanekaragaman jenis yang tergolong sedang $\left(\mathrm{H}^{\prime}=2,15\right.$ dapat mengindikasikan adanya gangguan atau berkurangnya kualitas lingkungan/habitat komunitas burung di areal mangrove Desa Passo, walaupun masih dapat mampu mendukung kehidupan komunitas burung yang ada.

\section{Habitat Burung di Areal Mangrove Desa Passo}

Habitat sebagai tempat hidup satwa burung diperlukan sebagai tempat untuk mencari makan, berlindung, berkembangbiak dan bermain. Salah satu kawasan yang dijadikan sebagai habitat satwa burung adalah areal mangrove.

Berdasarkan pengamatan pada stasiun/titik hitung yang telah ditentukan sebelumnya, dapat dijelaskan bahwa habitat komunitas burung di areal mangrove Desa Passo dapat dibedakan berdasarkan jenis-jenis flora penyusun vegetasi. Dari keenam stasiun yang telah dibuat, lima 
Keanekaragaman jenis satwa burung di areal mangrove Desa Passo Kecamatan Teluk Ambon Baguala (Maya. M. S. Puttileihalat, A. Tuhumury, J.Ch. Hitipeuw)

diantaranya didominasi oleh jenis Rhizophora dan Soneratia; sedangkan satu stasiun lainnya disusun oleh perpaduan antara Nipa dan Rhizophora.

Kawasan mangrove merupakan habitat marginal bagi jenis burung-burung terestrial. Burungburung terestrial biasanya memanfaatkan percabangan mangrove sebagai tempat beristirahat dan mencari makan, demikian juga untuk jenis burung-burung air memanfaatkan hutan mangrove sebagai habitat untuk mencari makan dan berbiak. Makanan dari satwa burung di kawasan hutan mangrove dapat berupa serangga, nectar, cacing, udang, kepiting dan ikan. Masing-masing jenis satwa burung memiliki kesukaan dan ciri khas untuk memilih makanannya.

Jenis satwa burung yang menjadikan areal mangrove Desa Passo sebagai habitatnya yaitu Walet Sapi (Collocalia esculenta), Trinil Pantai (Actitis hypoleucos), Gajahan Kecil (Numenius minutus Gould), Burung Madu Sriganti (Nectarinia jugularis), Cekakak Sungai (Todirhampus chloris), Pecuk Padi Belang (Microcarbo melanoleucos), Kuntul Kecil (Egretta garzetta), Kuntul Karang (Egretta sacra) dimana jenis-jenis burung tersebut melakukan aktivitas mencari makan, bermain dan berlindung dalam areal mangrove.

\section{KESIMPULAN}

Jumlah jenis satwa burung yang tercatat di areal mangrove Desa Passo sebanyak 11 jenis dari 9 genus, 7 famili, dan 7 ordo. Rerata jumlah individu yang tercatat selama kegiatan penelitian adalah sebanyak 197 ekor. Komposisi jenis burung di areal mangrove Desa Passo 72,73\% merupakan jenisjenis burung air, meliputi 4 ordo dari total 7 ordo, dan 4 famili dari total 7 famili, serta 6 genus dari total 9 genus; sedangkan 27,27 \% lainnya merupakan jenis-jenis burung terestrial. Keanekaragaman jenis burung di areal mangrove Desa Passo tergolong sedang, ini ditunjukkan dengan nilai indeks keanekaragaman sebesar 2,15 $\left(1<\mathrm{H}^{\prime}<3\right)$. Hal ini menggambarkan kemampuan komunitas burung pada hutan mangrove Desa Passo dalam merespon gangguan tergolong sedang. Areal mangrove Desa Passo merupakan habitat dari jenis Walet Sapi (Collocalia esculenta), Trinil Pantai (Actitis hypoleucos), Gajahan Kecil (Numenius minutus Gould), Burung Madu Sriganti (Nectarinia jugularis), Cekakak Sungai (Todirhampus chloris), Pecuk Padi Belang (Microcarbo melanoleucos), Kuntul Kecil (Egretta garzetta), Kuntul Karang (Egretta sacra) untuk melakukan aktivitas mencari makan, bermain dan berlindung. 


\section{DAFTAR PUSTAKA}

Alikodra, H.S, 1979. Dasar-dasar Pembinaan Margasatwa. Fakultas Kehutanan Institut Pertanian Bogor.

1990. Pengelolaan Satwa Liar Jilid I. Departemen Pendidikan Dan Kebudayaan, Direktorat Jenderal Pendidikan Tinggi, Pusat Antar Universitas Ilmu Hayati, IPB: Bogor.

Anonim, 2002. Keragaman Jenis Satwa Burung Dan Habitatnya Pada Beberapa Ketinggian Tempat Di Pulau Saparua Kabupaten Maluku Tengah. Skripsi

Arumasari. 1989. Komunitas Burung Pada Berbagai Habitat di Kampus UI, Depok. Skripsi Sarjana Biologi FMIPA Universitas Indonesia. Jakarta Bailey, J. A. 1984. Principleso Wildlife Management. John Wiley\& Sons, New York.

Buckland, S. T., Anderson, D. R., Burnham, K. P., Laake, J. L., Borchers, D. L., andThomas, L. (2001.). Introductionto Distance Sampling: Estimating Abundanceo Biological Populations. (Oxford University Press: Oxford.)

Farixedas, S., Linden, A., Piha, M., Cabeza, M., Gregory, R., Lehikoinen, A. (2020). A state-of-the-art review on birds as indicators of biodiversity: Advances, challenges, and future directions. Ecological Indicators 118 (2020), 1-10.

Helvoort, B.V. 1981. Bird Populations in The Rural Ecosistemso West Java. Nature Conservation Depertment. Netrherlands.

Irby J. Lovette, \& John W. Fitzpatrick, 2016. Why Study Birds? dalam Handbook Of Bird Biology. Third edition. Princeton University Press. United Kingdom.

Irwan, Z. D. 1992. Prinsip-prinsip Ekologi dan Organisasi Ekosistem Komunitas dan Lingkungan. Bumi Aksara. Jakarta.

Krebs, J. C. 1989. Ecological Methodology. Harper Collins Publisher, Inc. New York.

Monk, K. A, dkk.2000. Ekologi Nusa Tenggara dan Maluku. Dalhousie University/Canadian Internasional Development Agensy. Jakarta

Peterson R.T. 1980. Burung Pustaka Alam Life. Tiara Pustaka, Jakarta.Soegianto, A. 1994. Ekologi Kuantitatif: Metode Analisis Populasi dan Komunitas. Penerbit Usaha Nasional. Jakarta.

Saptono, M., Chatarina, M., \& Sigit, S. 2016. Kajian Perubahan Luas dan Pemanfaatan serta Persepsi Masyarakat terhadap Pelestarian Hutan Mangrove di Kecamatan Teluk Ambon Baguala. Jurnal GoeEco. Vol 2, No. 2. (177-183).

Soerianegara, I dan Indrawan, A. 1988. Ekologi Hutan Indonesia. Fakultas Kehutanan IPB. Bogor.

Walter, D. Koenig. 2016. Ecology of Bird Populations dalam Handbook Of Bird Biology. Third edition. Princeton University Press. United Kingdom.

Welty \& Baptista, 1988. Welty, J.C. and L. Baptista. 1988. The Life of Bird. New York: Sounders College Publishing.

Wiens, J. A. 1992. The Ecology of Bird Communities I: 241-374. Foundation sand Patterns. Cambridge University Press.

Wiersum, K. F. 1973. Wild Life and Management in Tropical Regions Agrig. Univ. Nat Conservation Departement, Wageningen

Wiryono, 2009. Ekologi Hutan. UNIB PRESS. Bengkulu. 